1993

\title{
Les Misérables Redux: Law and the Poor
}

Allan C. Hutchinson

Osgoode Hall Law School of York University, ahutchinson@osgoode.yorku.ca

\section{Source Publication:}

Southern California Interdisciplinary Law Journal. Volume 2, Number 2 (1993), p. 199-244.

Follow this and additional works at: https://digitalcommons.osgoode.yorku.ca/scholarly_works cc) (i) $\Theta \Theta$

This work is licensed under a Creative Commons Attribution-Noncommercial-No Derivative Works 4.0 License.

\section{Recommended Citation}

Hutchinson, Allan C. "Les Misérables Redux: Law and the Poor." Southern California Interdisciplinary Law Journal 2.2 (1993): 199-244.

This Article is brought to you for free and open access by the Faculty Scholarship at Osgoode Digital Commons. It has been accepted for inclusion in Articles \& Book Chapters by an authorized administrator of Osgoode Digital Commons. 


\title{
ARTICLES
}

\section{LES MISÉRABLES REDUX: LAW AND THE POOR}

\begin{abstract}
Allan C. Hutchinson*
Certainly they appeared utterly depraved, corrupt, vile and odious; but it is rare for those who have sunk so low not to be degraded in the process, and there comes a point, moreover, where the unfortunate and the infamous are grouped together, merged in a single and fateful word. They are les misérables - the outcasts, the underdogs. And who is to blame?
\end{abstract}

Victor Hugo ${ }^{1}$

Each day a poignant and pathetic ritual is performed outside courthouses. Osgoode Hall in downtown Toronto is no exception. Like most courthouses and seats of the profession's ruling body, it is at the center of the city's legal life. Built in 1832, it is an impressive building that affects the imposing stylistic tradition of classical architecture. With its monumental stone balustrade and fluted Ionic columns, the facade's grandeur is intended to exalt the law and awe the citizen; it is a modest monument to law's assumed majesty and prestige. ${ }^{2}$ Yet, in almost time-honored tradition, a street person or two stands outside the ornamental wrought-iron railings that encircle it. Most lawyers walk past them, but some stop to place a coin in their outstretched hands. This sad scene has been commonplace throughout the century and across the continent.

Just as depressing and troubling is the fact that what goes on outside the court is only a more obvious and less refined enactment of what goes on inside the courts. That pitiful pageant and personal exchange symbolizes the relation between the law and the poor. It is a daily confirmation

* Osgoode Hall Law School, York University, Toronto. Many thanks to Pam Carpenter, Blair Holder and Rose Della Rocca for comments and support.

1. Victor Hugo, Les Misérables 639-40 (Norman Denny trans., 1976) (1862).

2. See Kimberly R. Jones, House of Justice: Feminism in Architecture, 3 YALE J.L. \& FEMINISM 281 (1991) (a provocative account of legal buildings). 
of the law's cruel indifference to the plight of society's les misérables. For all its fine rhetoric and noble posing, the law and its guardians have little time for the street people. Shepherded from its swept steps and manicured lawns, they must hover at its perimeters and hope for the occasional gesture of personal charity. Figuratively and literally, law remains aloof and out of bounds for them. The law is exactly as it is represented in its architectural embodiment: an intimidating bastion of power and privilege that houses the establishment's judicial representatives who contrive to turn a blind eye to the underclass.

The poor and the disenfranchised might be occasionally invited into its great halls, but their visits are temporary and tenuous. They remain only as long as they adopt a polite and ingratiating posture of supplication, make an appropriate display of gratitude and affect a suitable attitude of contrition about their condition. As for the street people, they hold few illusions about the law's willingness to do anything that will truly address and alleviate their situation. It is still for the law to give and the poor to receive. They are not allowed to take what is theirs; they continue to be dependent upon the law's occasional gesture of idiosyncratic generosity. Such a relationship impoverishes the law as much as it demeans the poor. Through its condescending acts of benevolence, the law manages to affirm its own power and authority at the same time that it reinforces the powerlessness of the poor.

In this essay, I want to validate this rather harsh and stark depiction of the law's institutional callousness and to condemn its pathological incompetence in responding to the needs of the most deprived and desolate in the community. In order to throw a more illuminating and less bombastic light upon the matter, I will enlist the help of Victor Hugo's Les Misérables. ${ }^{3}$ Although written 150 years ago, it retains an appalling similarity to contemporary conditions and challenges. By focusing on that work's themes and imagery, I hope to demonstrate the structural failings of courts as a forum for social transformation and to chastise academics for their complicity in the misguided efforts to litigate an end to poverty and its pernicious effects. In particular, I want to revisit the rights debate and, in light of recent interventions, explore the role that rights litigation might play in a revised vision and practice of egalitarian politics. While rights talk is not always inimical to social transformation, I contend that it is always limited and limiting. At best, I can tolerate, but have little faith in, the possibility of progressive intervention through rights litigation.

3. Supra note 1 . 


\section{HUGO'S HARANGUE}

For better and worse, Victor Hugo (1802-85) is a titan of Western literature. ${ }^{4}$ Like most great writers, he transformed the conventional standards of artistic merit as he exceeded them. A prodigious writer of poetry, drama and prose, his work manages to traverse the spectrum of literary styles and sensibilities. Possessing technical skills and mythic imagination in uncommon abundance, he both procreated and perfected a novelistic genre that combined soaring romanticism with earthy realism on the grandest scale. With his consummate command of language, Hugo wrote novels that reflected his intellectual and emotional bravura. The masterpiece of his extensive oeuvre is Les Misérables. Along with Notre Dame de Paris, this work represents the high-water mark of his literary genius. It is, at once, a sociological essay, adventure thriller, sermon, historical chronicle, educational text, gothic romance, political pamphlet, philosophical meditation and much more.

Yet, never only a brilliant virtuoso, Hugo placed his huge literary talents in the service of popular suffrage: "Peer through the heart of the people and you will discover the truth."' A precocious talent of middleclass parentage, he quickly abandoned his family's Bonapartism and traditional defense of conservative values. Over the years and in spurts and starts, he became an outspoken critic for a republican form of government. He was an active participant in political life and, after the revolution of 1848 , sought to rally workers against state oppression. ${ }^{6}$ This led to his long, but productive exile from France in the Channel Islands. By the time Les Misérables was published in 1862, Hugo had become a committed democrat and socialist. $\mathrm{He}$ was an avowed defender of "the absolute principle of democracy"7 under which any attempt to deprive people, as individuals or as a community, of power amounted to usurpation. Allied to this was an enthusiastic espousal of

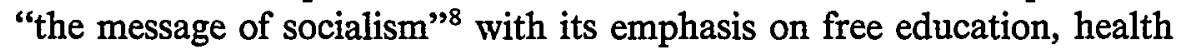
care and the democratization of private property in "the union of material and moral greatness." 9 Political struggle and social enlightenment were the touchstones of his own literary expectations. He understood

4. See Foster E. GuYer, The TItAN Victor Hugo (1955); Victor Hugo (Harold Bloom ed., 1988).

5. Hugo, supra note 1 , at 509.

6. See Elliotr M. Grant, The Career of Victor Hugo (1945); ANdre Maurois, OLYMPIO: THE LIFE OF VICTOR HUGO (Gerard Hopkins trans., 1956).

7. See Hugo, supra note 1, at 718.

8. See id. at 724 .

9. Id. 
that salvation is not given from above, through God or Law, but is taken from below by the people themselves. ${ }^{10}$

The general storyline and structure of Les Misérables is well known and needs little rehearsal. By combining cosmic themes with domestic details, Les Misérables manages to be both a social testimony to human suffering and an epic tale of human deliverance. Possessing a seemingly inextinguishable belief in the spiritual possibilities of people, Hugo presents a melodrama of human perfectibility in which, through will and circumstance, the corrupted become cleansed: "Is there not in every human soul . . . an essential spark, an element of the divine, ... which goodness can preserve, nourish, and fan into glorious flame, and which evil can never quite extinguish?"11 His ultimate ambition was not the individual salvation of a human soul, but the collective resurrection of humankind. Encompassing the vast canvass of French history in the first forty years of the last century, the narrative thread is the extraordinary life and travails of Jean Valjean as convict, industrialist, fugitive, protector, philanthropist and protagonist. Through him, Hugo introduces a sprawling cast of memorable characters and romantic stereotypes-the tragic Fantine, the malevolent Thénardier, the angelic Cosette, the lovelorn Marius, the uncompromising Enjolras, the impish Gavroche and, of course, the remorseless Javert. But, throughout the book, the dramatis personae seem only convenient constructs through which the epic stuff of life and death is animated and acted out. More than being an extravagant tableaux of a larger-than-life Paris, it is a sweeping saga of the struggle between good and evil, light and dark, and sublime and grotesque.

Les Misérables is often too stylized, didactic, indulgent and dithyrambic; Hugo's proselytizing tendencies occasionally eclipse his poetic gifts and his sociological ascriptions sometimes overwhelm his redemptive aspirations. But, even flawed as all romantic novels are, it bears heroic witness to the social consciousness and conditions of the time. More than that, Les Misérables can still speak to us across history. Its themes remain as relevant today as they were shocking in yesteryear; they resonate troublingly with the social conditions of fin-de-siécle America. In the last 150 years, much has changed, but much has stayed the same. The plight of the downtrodden and disenfranchised is a

10. This assessment is by no means universal. Some contend that Les Misérables is basically a political book whose commitment to revolutionary change is more apparent than real, and which hides a deep attachment to order and continuity. See VICTOR BROMBERT, VICTOR HUGO AND THE VISIONARY NOVEL 135-39 (1984).

11. Hugo, supra note 1, at 98. 
powerful and permanent feature of contemporary life in North America. Moreover, law continues to be long on words and short on action.

In this essay, I intend to draw upon only a few of the threads that comprise the thematic tapestry of Les Misérables. Of course, the book amounts to much more and much less than these particular and selective motifs. ${ }^{12}$ I intend to pursue three related angles that provide a neat organizational structure for the essay: the condition of poverty and its apprehension by the privileged; the self-serving ethics and false esteem of the philanthropic citizen; and the crass antagonism of law and its officers to a truly transformative vision and practice of egalitarian justice. Together, these themes combine to form a strong indictment against law and its role in les misérables' continued suffering.

The first theme is that of poverty. Like Dickens and Orwell, ${ }^{13}$ Hugo captures the suffering and degradation of abject poverty and destitution in all its graphic and nauseating detail. For him, misery is a social condition and not an individual state of mind; its eradication requires action to change the material and structural circumstances of life rather than moral suasion and discipline urged upon individual minds. Yet, generally resisting the temptation to romanticize those "[a]t the level of utmost poverty [whose] wits are too dulled to complain at misfortune or give thanks for a benefaction," 14 Hugo never robs them of their dignity or pride. He places blame for the continuing conditions of miserable poverty squarely on the padded shoulders of those who thrive. Lambasting the privileged's pitiful demonization or patronization of unprivileged communities as a breeding ground for crime and unrest, the real enemy is not outsiders, but "[i]t is ourselves we have to fear[; p]rejudice is the real robber, and vice the real murderer."15 Even the most enlightened legal actors treat les misérables as a race apart. Different from themselves, they must be tolerated, but they need not be embraced. The judgments of the courts in Young v. New York City Transit Authority ${ }^{16}$-and their framing of the issues before them-rather than the decisions themselves,

12. It seems worthwhile emphasizing that I do not offer my interpretation of Les Misérables as the correct, true, best, only or whatever reading. See AlLaN C. Hutchinson, Dwelling on the THRESHOLD (1988). It is simply one attempt to put my reading to topical effect. For other interpretations, see, e.g., Richard B. Grant, The Perilous Quest 154-76 (1968); Bloom, supra note 4.

13. See Charles Dickens, David Copperfield (1863); George Orwell, Down and OUT IN PARIS AND LoNDON (1933).

14. Hugo, supra note 1 , at 817 .

15. Id. at 42 .

16. 729 F. Supp. 341 (S.D.N.Y. 1990), rev'd in part and vacated in part, 903 F.2d 146 (2d Cir. 1990), cert. denied, 498 U.S. 984 (1990). 
rely on the supercilious and condescending image of beggars that informs and grounds the law.

The second theme is derivative of the first. Whereas the first speaks to the general relation between the haves and have-nots, the second explores its expression in the individual dealings of the pauper and the philanthropist. Although "[i]gnominy thirsts for respect,"17 those who offer charity to the poor do so as much in the spirit of self-righteousness as from a sense of solidarity. Philanthropists are too often motivated by a need to assuage their own guilt than by a wish to eradicate poverty. In a provocative contribution to the legal debate over rights and begging, Helen Hershkoff and Adam Cohen run this risk of philanthropic patronization. ${ }^{18}$ They seek to speak for beggars and to alleviate their condition by arguing that begging is fully protected speech under the First Amendment. ${ }^{19}$ However, laudable intentions do not excuse lamentable effects. Their proposal to establish a right to beg is more likely than not to inhibit rather than enhance the long-term prospects of les miserables for personal and collective salvation.

The third theme is more overtly jurisprudential in focus and design. For Hugo the law is very much part of les misérables' problems rather than a resource in their resolution. The law is a conservative and cold force that not only holds in place the social conditions of poverty, but also works its own oppression when les misérables fall under its influence. The epic encounters between Jean Valjean and Inspector Javert represent the clash between the popular pressures for social change and the established forces of authoritarian order. Notwithstanding the dismal history of efforts to effect social change through the courts, contemporary activists are unable to resist the allure of rights-talk and still tend to look to the courts as the preferred forum of transformative choice. This is a fundamental error and a tactical mistake. If there is to be real change for the progressive good, it will not come through the courts. Indeed, only lawyers seem to imagine that it could or will.

\section{CHEAP TALK}

Like Victor Hugo's Paris of the last century, the contemporary streets of American cities are home to legions of the wretched and

17. Hugo, supra note 1, at 86 .

18. See Helen Hershkoff \& Adam S. Cohen, Begging to Differ: The First Amendment and the Right to Beg, 104 HARV. L. REv. 896 (1991).

19. See infra part III.A. 
dispossessed. Without support or shelter, these beggars are found everywhere, but "become lost in that cold murk that envelops solitary destinies, the distressful shadows wherein disappear so many unfortunates in the sombre progress of mankind."20 Insult is added to injury by the fact that, although the United States is the richest country in the world, it has the greatest disparity between the income and wealth of the rich and poor; the top ten percent of households control about seventy percent of the wealth and the bottom ten percent live below the poverty line. ${ }^{21}$ In a country of plenty, homelessness is a condition that afflicts over 500,000 people ${ }^{22}$ and amounts to a national disgrace. The enormity of the problem reduces the pain-searing cry of personal tragedy to the sedated murmur of a collective statistic.

\section{A. Poor Relations}

While the suffering of today's les misérables is everywhere and always present, society has developed various discursive devices by which to comprehend and contain them. Indeed, like all languages, the rhetoric of poverty creates and classifies reality at the same time that it responds to and is limited by that reality: "how we talk and argue about poverty reveals what we believe about ourselves and others." 23 It is through the act of categorization and labelling that a particular reality is apprehended and maintained. Reality's identity and meaning is never simply found or observed, but is always imposed and located within a particular ideological structure of discourse; it is less a matter of technical refinement and more a case of creative designation. Mindful that no mode of discourse passively represents instead of actively producing, the world must be spoken for, and often manages to communicate in the accent of established interests. As such, the rhetoric of poverty has its own history and politics because the privilege of naming is part and parcel of the power to control. ${ }^{24}$

20. Hugo, supra note 1 , at 94 .

21. Kevin Phillips, The Politics of Rich and Poor 8-9 (1990). The situation is proportionately worse for the young, women and people of color. Id. at 202-09; see also WiLliam J. Wilson, The Truly Disadvantaged (1987).

22. Martha R. Burt \& Barbara E. Cohen, America's Homeless: Numbers, Characteristics, AND Programs That Serve Them 32 (1989).

23. Thomas Ross, The Rhetoric of Poverty: Their Immorality, Our Helplessness, 79 GEO. L.J. 1499,1502 (1991).

24. For a more general description of the discursive element of politics, see David Cohen \& Allan C. Hutchinson, Of Persons and Property: The Politics of Legal Taxonomy, 13 Dalhousie L.J. 20 (1990); Martha Minow, Making Ali The Difference (1990). 
Vast intellectual and ideological resources are expended in establishing and maintaining the rhetoric of poverty. The rhetoric of poverty attempts to provide an account of poverty that is able both to recognize the plight and pain of the poor and to confirm the lack of responsibility by the privileged for that condition of inequality. A way of speaking is sought that allows people to identify the suffering of the poor without having to identify with the poor. As such, it is obviously the voice of the non-poor that speaks from the vantage point of its own privilege. The poor are denied access to both material and intellectual resources. Shunned and silenced, they suffer the double indignity of being consigned to existential penury and intellectual purgatory. Deprived of a language through which to speak, their experience is diminished and distanced from the reality that the rhetoric of poverty claims to represent.

The chief rhetorical maneuver in the discourse of poverty is the stigmatization of the poor as lazy, unmotivated, weak-willed, profligate and dull. They are a thoroughly undisciplined group whose poverty "in the land of opportunity ... has seemed not only a misfortune but a moral failure."25 In short, with a bad attitude and even shoddier work habits, the poor are responsible for their own misfortune and, therefore, its future amelioration; life is not a handout. It is a discourse of difference in which the poor are treated as a race apart. While they are considered to share a common humanity with the rest of society, they are marked by their poverty as less deserving of common solicitude. Because they do not play a full part in the production of society's wealth, they are in no position to demand or expect a full share in its distribution. In the lexicon of strict liberalism, individuals must assume full responsibility for their own lives because it is the individual, and not the society of which they are part, that determines their role and its possibilities.

The effect of this discursive dissemblance is two-fold. First, it presents the causes of poverty as individual and personal rather than collective and public. Being based on a lack of moral fiber and substance, attention is focused upon the state of particular person's moral constitution and not upon the social and economic structure into which people are born and live. Poverty is not a function of present arrangement, but is a malfunctioning of certain sectors of the population. As such, solutions are sought through programs of moral regeneration and civic restoration in which the protestant virtues of discipline, monogamy, sobriety,

25. Michael Katz, IN The Shadow of The PoOR House (1986); see also Michael Katz, THE UNDESERVING POOR (1989). For a topical account of "why the poor are still with us," see Joel Schwartz, The Moral Environment of The Poor, PUB. INTEREST, Spring 1991, at 21. 
thrift and hard work are inculcated. Initiatives intended to alter the redistribution of economic resources are placed lower on the social agenda. For example, prostitutes are more castigated for their failure of moral chasteness than they are sympathized with for their lack of other means of economic survival. ${ }^{26}$

Secondly, and as an obvious corollary of the first effect, this vocabulary of stigmatization enables the privileged to affect an exasperated posture of helplessness. They engage in much wringing of hands and creasing of brows. Yet, this way of thinking about poverty excuses the privileged from accepting or eradicating the more structural cause of poverty. It justifies the privileged's apparent helplessness in the face of the poor's own intractability in improving their moral outlook. As with most forms of hypocrisy, it relieves the privileged from the painful duty of accepting responsibility and beginning to do something to change matters. It reassures them in their own privilege and confirms their earned entitlement to a life without hunger. Like most forms of justification, the rhetoric of poverty is generated for the privileged's own consumption, for it allows them to continue in their own lives without too much interruption or angst. Living a life of poverty, les misérables have little need for such instruction or insight.

Hugo fully understood this discourse of poverty and difference. While he himself never experienced the severe deprivations of utmost poverty, his account in Les Misérables is convincing and moving. $\mathrm{He}$ grasps not only the poor's suffering, but the privileged's sanctimony. His literature provides a stark challenge to the transparency of the elite's selfserving apologetics. However, Hugo does not always resist the temptation to judge the poor and offer the opinion that there is "in its most noisome and ferocious aspects, a form of social ugliness that was perhaps even more repulsive than the evil rich: namely, the evil poor."27 However, he rejected entirely the view that les misérables were the architects of their own moral degeneration and material poverty: " $[t]$ he very words accepted as terms of abuse-down-and-outs, riff-raff, mobocracy-point, alas, rather to the faults of those who rule than to the sins of those who suffer, to the misdeeds of privilege rather than to those of the disinherited." 28 In this, Hugo ensures that his writings are not fodder for the privileged's propaganda, but instead, oblige the privileged to confront, at

26. See Jody Freeman, The Feminist Debate Over Prostitution Reforms: Prostitutes' Rights Groups, Radical Feminists and the (Im)possibility of Consent, 5 BERKELEY WOMEN'S L.J. 75 (1990).

27. See Hugo, supra note 1, at 739.

28. Id. at 987. 
least, their own rhetorical complicity in the continuing dominion of contemporary social conditions.

The modern tendency to abstract the poor, to portray them as essentially different and, thereby, to distance the poor from privileged purview and responsibility are forcefully captured in Hugo's famous characterization of the hapless Marius, a confused and idealistic law student who bears a strong resemblance to the young Hugo. Marius falls madly in love with Cosette. But, when she moves away without trace, he is soon thrown into despair. Already enduring a severely frugal and ascetic life, he falls into the abyss of penurious hardship. After five years of living in this tortured state, he becomes curious about the family in the neighboring garret who seem to live in greater squalor than his own. He has a chance encounter with the young daughter-"an ill-treated girl with the eyes of a grown woman; a blend of fifty and fifteen; one of those creatures, at once weak and repellent, who cause those who set eyes on them to shudder when they do not weep."29 Confronted by a life of most utter destitution and loveless grief, Marius recognizes that he has not until then encountered the true meaning and hopelessness of real poverty. In a stern lecture, Hugo delivers a strong rebuke:

People reduced to the last extremity of need are also driven to the utmost limit of their resources, and woe to any defenseless person who comes their way. Work and wages, food and warmth, courage and goodwill-all this is lost to them. The daylight dwindles into shadow and darkness enters their hearts; and within this darkness man seizes upon the weakness of woman and child and forces them into ignominy. No horror is then excluded. Desperation is bounded only by the flimsiest of walls, all giving access to vice and crime.

Health and youth, honor and the sacred, savage delicacy of stillyoung flesh, truth of heart, virginity, modesty, those protective garments of the soul, all are put to the vilest of uses in the blind struggle for survival that must encounter, and submit to, every outrage. Fathers, mothers, sons, daughters, brothers, men and women alike merge into a composite, like a mineral alloy, in the murky promiscuity of sexes, relationships, ages, infamy and innocence. They huddle together, back to back, in a kind of spiritual hovel, exchanging glances of lamentable complicity. How pale they are, those unfortunates, how cold they are! They might be the inhabitants of a planet far more distant from the sun than our own.

29. Id. at 633. 
To Marius the girl was in some sort an emissary of that underworld, disclosing a hideous aspect of its darkness. He was near to reproaching himself for his habit of abstraction and for the love-affair which until then had prevented him from giving a thought to his neighbors. The payment of their rent had been an automatic response, an impulse that might have occurred to anyone; he, Marius, should have done better. Only a thin partition separated him from that small cluster of lost souls groping in darkness and sundered from the living world; he had heard them living, or rather suffering, within a few yards of him-and he had paid no attention. All day and every day he had been conscious of their movements through the wall as they came and went and talked together, and he had not listened. Groans had been mingled with the words they spoke, but he had not heeded them. His thoughts had been elsewhere, squandered in dreams, infatuation, while these, his fellow-creatures and brothers in Christ, were slowly rotting beside him, abandoned to their agony. Indeed, it seemed to him that he was a part of their misfortune and had aggravated it. If they had had a different neighbor, one less self-absorbed and more concerned for others, a man of normal, charitable instincts, their desperate state would not have gone unnoticed, their distress-signals would have been heard, and perhaps they would have been rescued by now. Certainly they appeared utterly depraved, corrupt, vile and odious; but it is rare for those who have sunk so low not to be degraded in the process, and there comes a point, moreover, where the unfortunate and the infamous are grouped together, merged in a single, fateful word. They are les misérables-the outcasts, the underdogs. And who is to blame? Is it not the most fallen who have most need of charity? ${ }^{30}$

In this moment of Marius' revelation, Hugo pierces the rhetorical veil that hides the privileged and self-absorbed from seeing the suffering that surrounds them and that their own privilege sustains: they look, but they do not see. In love with themselves, they are effectively blinded to their own culpability in the pain and torment of their fellow citizens. This indifference is not only the measure of the callous or the malevolent; the callous or the malevolent at least have the virtue of honesty. As with Marius, even the most sensitive and informed can remain truly unconscious of the brute conditions that constitute poverty. Their own relative privilege only serves to place the complete lack of privilege in even starker relief. Indeed, the judges in Young are such an example.

30. Id. at $638-40$. 


\section{B. FOREVER YOUNG}

William B. Young, Jr. and Joseph Walley were homeless. ${ }^{31}$ They spent their day soliciting money for themselves in the relative warmth and shelter of the New York City transit system; they used the money to buy food, medicines and other essentials. ${ }^{32}$ Because they slept in shelters at night, they received reduced public assistance of $\$ 21.50$ every two weeks. ${ }^{33}$ They approached transit users, asking them for money and answering any questions that they might have. ${ }^{34}$ In 1989, Young and Walley were frequently escorted from the premises by the police in consequence of "Operation Enforcement," and threatened with criminal prosecution. ${ }^{35}$ After a passenger survey, the Transit Authority had decided to implement more effectively the long-standing prohibition on begging and panhandling in the subway. ${ }^{36}$ At the same time, the Transit Authority had amended its regulations to permit, in limited circumstances, charitable solicitation on its premises. ${ }^{37}$

Through the Legal Action Center for the Homeless, Young and Walley claimed that their constitutional rights had been infringed and that the ban on begging was a pretext for evicting the homeless and destitute from the subway system. ${ }^{38}$ The doctrinal core of the legal issues was whether the prohibition of begging in a public utility violated the First Amendment. In particular, it had to be determined whether begging was protected speech or restrainable conduct and whether the subway system was a public forum for the purpose of first amendment analysis. At first instance, District Judge Leonard B. Sand decided that begging was protected speech ${ }^{39}$ and that the New York City Transit System was a designated public forum. ${ }^{40}$ Accordingly, the regulations were held to violate Young and Walley's right to free speech. ${ }^{41}$ However, on appeal the Second Circuit reversed that decision, with Judge Meskill dissenting in part. The court held that the regulations were not in contravention of the First

31. See Young v. New York City Transit Auth., 729 F. Supp. 341, 344 (S.D.N.Y. 1990), rev'd in part and vacated in part, 903 F.2d 146 (2d Cir. 1990), cert. denied, 498 U.S. 984 (1990).

32. See Young, 903 F.2d at 166 (Meskill, J., concurring in part and dissenting in part).

33. Id.

34. Young, 729 F. Supp. at 345.

35. Id.

36. See Young, 903 F.2d at 148-49.

37. See id. at 148.

38. Young, 729 F. Supp. at 349.

39. See id. at 356 .

40. See id. at 358.

41. See id. at 360 . 
Amendment: begging was not expressive conduct, ${ }^{42}$ and, notwithstanding that charitable solicitation was permitted, the subway was not a designated public forum. ${ }^{43}$

The holdings of the two courts traversed traditional doctrinal territory. The different approaches to and resolution of these perennially problematic issues of identifying protected speech and designating public fora are interesting and revealing in themselves. ${ }^{44}$ But, for my objectives, the more significant and fascinating dimension of the holdings and the counsels' arguments is their location within an identifiable and contestable mode of rhetorical discourse about poverty. By making implicit recourse to a particular moral medium and universe, the judges assumed a shared understanding and representation of poverty and its social intelligibility. In doing so, they perpetuated a world-view whose intellectual lineage and historical pedigree can be traced back to Hugo and before. Inadvertently, they bear eloquent witness to the debilitating effects of that rhetoric and give a judicial imprimatur to its legitimacy. Inherent in their holdings is the assumption that the poor are different and undeserving, intimidating, unruly, and at the root of much of the chaos and crime that threatens the hard-working community. While the plight of the poor is to be regretted, their suffering is not for the rest of society to endure or be responsible for.

The whole issue in Young initially was framed and presented by the Transit Authority's lawyers in stark oppositional terms that distinguish between the poor and homeless, and the hard-working denizens of New York. For the Transit Authority, the regulations were motivated by concerns for public safety and not the content of the beggars' message. Drawing upon a lengthy study commissioned in 1988, the Transit Authority contended that its decision to amend and enforce more actively existing regulations was a response to the social fact that the public experiences beggars as an intimidating and discomforting source of harassment. ${ }^{45}$ The already congested and crowded environment of the subway was exacerbated by the presence of beggars and the passengers' high levels of fear and anxiety were heightened. ${ }^{46} \mathrm{~A}$ consulting sociologist concluded that, whereas ordinary city streets allow "fate-control"

\footnotetext{
42. See Young, 903 F.2d at 153-54.

43. See id. at 161.

44. See Allan C. Hutchinson, Talking The Good Life: From Free Speech to Democratic Dialogue, 1 YALE J.L. \& LIB. 17 (1989).

45. See Young, 903 F.2d at 149-50.

46. See id. at 149. In describing the subway, the court draws upon a Dantean imagery and evokes Hugo's account of Paris' underground system of sewers:
} 
(i.e., the ability to avoid and move away from an intimidating person), the constrictive subway system ensures that begging is inherently aggressive, disruptive, startling and potentially dangerous. ${ }^{47}$ Indeed, "this 'subset of the homeless' should not be encouraged to beg and panhandle in the system "for their own well-being. " 48 This is cruelly ironic in that they are only there in the first place to attempt to stave off hunger and to preserve the lowest form of well-being.

In his opinion for the Court of Appeals on behalf of Judge William Timbers and himself, Judge Frank Altimari slipped easily into the rhetoric of poverty and gave express approval to the defendant's characterization of the problem and its personnel. He made it clear that

it is not the role of this court to resolve all the problems of the home-

less, as sympathetic as we may be. We must fulfill the more modest task of determining whether the [Transit Authority] may properly ban conduct that it finds to be inherently harmful in the subway system. ${ }^{49}$

For him, much of this resolution could be accomplished by resort to common sense: "[W] hat common sense beckons the law ordains." 50 Part of this common sense was an understanding and acceptance that les misérables are "threatening, harassing and intimidating," 51 that "begging in the subway often amounts to nothing less than assault, creating in the passengers the apprehension of imminent danger,"52 and that it "amounts to nothing less than a menace to the common good." 53

By drawing upon the demonizing rhetoric of poverty, Judge Altimari is able to instill his judgment with a semblance of reason and rationality: "Unlike burning a flag, wearing a black arm-band, sitting or marching, begging in the subway is experienced as transgressive conduct whether devoid or inclusive of an intent to convey a particularized message." "54 Yet, his decision that begging is not sufficiently expressive to be protected speech flies in the face of "right reason . . . and common

The New York City subway system transports approximately 3,500,000 passengers on an average workday, operates 24 hours a day, seven days a week, and consists of 648 miles of track, 468 subway stations and over 6,000 subway cars. Many parts of the subway system are almost 100 years old. In a routine of New York City life, each day a multitude descends the steep and long staircases and mechanical escalators to wait on narrow and crowded platforms bounded by dark tunnels and high-powered electrical rails.

Id.; see also Hugo, supra note 1, at 1061-75.

47. See Young, 903 F.2d at 150.

48. Id.

49. Id. at 156-57.

50. Id. at 153 .

51. Id. at 154 .

52. Id. at 158 .

53. Id. at 156 .

54. Id. at 154 . 
sense." 55 While its raison d'etre lies in the potential transfer of money, begging is surely the most basic and compelling kind of communication. The silent outstretched hand or the rattle of a cup comes closest to expressing most profoundly and poignantly the ineffable quality of destitution. Those dumb gestures articulate more fully the pathetic poetry of poverty that Keats's poems, Donne's sermons, and Hugo's prose only stutter and stammer to convey. ${ }^{56}$

For those unconvinced by his invocation of the law's common sense, Altimari argues that, even if "begging and panhandling possess some degree of a communicative nature," $" 57$ regulation is permissible if there is a sufficiently important and substantial government interest at stake. ${ }^{58}$ In a subtle and passing reference to Renton v. Playtime Theatres, ${ }^{59}$ he suggests that beggars and the purveyors of pornographic films are similar social characters and that their communicative activities are similarly devoid of redeeming social value. Having unfairly lumped together the destitute and the depraved, the judge moves to a resounding resolution of the legal problem that comes from and empirically confirms the disabling discourse of difference:

The governmental interests in the prohibition of begging in the subway are more fully elucidated when the harms to be avoided are juxtaposed with the good to be sustained. The subway is not a domain of the privileged and powerful. Rather, it is the primary means of transportation for literally millions of people of modest means, including hardworking men and women, students and elderly pensioners who live in and around New York City and who are dependent on the subway for the conduct of their daily affairs. They are the bulk of the subway's patronage, and the City has an obvious interest in providing them with a reasonably safe, propitious and benign means of public transportation. In determining the validity of the ban, we must be attentive lest a rigid, mechanistic application of some legal doctrine gainsays the common good. In our estimation, the regulation at issue here is justified by legitimate, indeed compelling, governmental interests. We think that the district court's analysis reflects an exacerbated deference to the alleged individual rights of beggars and panhandlers to the great detriment of the common good. ${ }^{60}$

55. Id.

56. Contra id. (quoting Cohen v. California, 403 U.S. 15, 26 (1971) (quoting Winters v. New York, 333 U.S. 507, 528 (1948) (Frankfurter, J., dissenting))).

57. Id. at 157.

58. See id. (applying O'Brien test).

59. See id. at 160 (citing Renton, 475 U.S. 41 (1986)).

60. Id. at 158. 
In this passage, all the familiar motifs and imagery are present: the hardworking majority, the dangerous poor, the common good, the reasonable authorities and the sensitive judge. Judge Altimari succeeds in completely denying the beggars' own sense of reality and depicting the advantaged in society as being harshly treated by the recalcitrant poor. Accordingly, the court is able not only to uphold the Transit Authority's regulation, but also to do so in a way that does not rely upon a "mechanistic application of some legal doctrine."61 Instead, it makes a proud appeal to the authoritative dictates of social justice and common decency.

Although Judge Sand and Judge Meskill reached conclusions that are more supportive of beggars, they still indulged in the patronizing rhetoric of poverty. Judge Sand had no qualm with the idea that begging was an expressive plea for charity: "While often disturbing and sometimes alarmingly graphic, begging is unmistakenly informative and persuasive speech." 62 In a short historical survey of begging, Judge Sand acted preemptively in giving the lie to the Court of Appeals's efforts "to suggest that begging has been universally viewed with the rancor and enmity of, say, obscenity."63 Yet, the overall tone and effect of his judgment was to reinforce the rhetoric of poverty's core idea that the poor are essentially different and potentially different: "A true test of one's commitment to constitutional principles is the extent to which recognition is given to the rights of those in our midst who are the least affluent, least powerful and least welcome." ${ }^{64}$ While he demonstrated a genuine solicitude for the plight of beggars like Young and Walley, tipping the constitutional balance in their favor, he accepted the validity of the hardworking majority's interests in being relieved from the discomfort that results from face-to-face confrontations with beggars. Also, he relied on the same assumptions when he found that time, place and manner restrictions that confine beggars to more marginal and less obvious vicinities were acceptable.

In his opinion, Judge Meskill comes closest to accepting the poor's own account of reality. Rejecting the notion that charitable solicitation can be meaningfully and genuinely distinguished from begging, he notes:

In the seclusion of a judge's chambers, it is tempting to assume that beggars could obtain jobs and spend their free time distributing leaflets or buttonholing passersby in the subway to further the cause of the
61. Id.
62. Young, 729 F. Supp. at 352.
63. Id. at 353 .
64. Id. at 360 . 
homeless and poor. The record in this case, however, permits no such speculation. . . . To suggest that these individuals, who are obviously struggling to survive, are free to engage in First Amendment activity in their spare time ignores the harsh reality of the life of the urban poor. ${ }^{65}$

Nevertheless, like Judge Sand, Judge Meskill remains ensnared within the privileged rhetoric of poverty. By recognizing that the interests that the Transit Authority was advancing-such as the protection of the public from harassment, preservation of the quality of life, and maintenance of a safe transit system-were legitimate and significant, he engages in the dominant discourse in which there are the "hard-working New Yorkers who rely on the subway system" and the belligerent beggar. Furthermore, by distinguishing between "a homeless person politely requesting money" and "the aggressive panhandler who accosts and intimidates subway riders," $"$ "he reveals that beggars are only acceptable on the advantaged's own terms and that beggars are not entitled to express the genuine anger or resentment they may feel. Sadly, even the most enlightened of the four judges held the view that form is more important than substance; protocols of civility and politeness take priority over real suffering and distress.

\section{BEGGAR YOUR NEIGHBOR}

Even if the judges in Young, as "sympathetic"67 as they claimed to be, felt constrained by the judicial role from tackling the problem of homelessness, academic commentators suffer from no such limitations. As especially privileged members of society, legal scholars are cushioned against risk and therefore must take full responsibility for their actions or lack of them. Like the best kind of fools, they must go where others fear to tread. Yet all that most of them can offer is compassion and rights. For instance, in the case of the homeless, considerable scholarly energy is devoted to establishing and defining a right to shelter. ${ }^{68}$ As the academic analogue to many well-intentioned philanthropists, legal scholars respond to social problems not with social solutions, but with the bestowal of legal rights.

65. Young, $903 \mathrm{~F} .2 \mathrm{~d}$ at $165-66$ (Meskill, J., concurring in part and dissenting in part).

66. Id. at 168.

67. See Young, 903 F.2d at 156-57.

68. See Patricia Siebert, Homeless People: Establishing Rights to Shelter, 4 LAw \& INEQ. J. 393 (1986); Note, A Right to Shelter for the Homeless in New York State, 61 N.Y.U. L. REv. 272 (1986). 


\section{A. INDETERMiNATELY SPEAKING}

In their daring rejoinder to Young, Helen Hershkoff and Adam Cohen seek to alleviate the beggar's condition by arguing that begging is fully protected speech under the First Amendment. ${ }^{69}$ Their larger concern is to engage political attention and, by making "it impossible for [mainstream listeners] to be oblivious to the poverty in their midst,"70 place its eradication firmly on the agenda of social reform. Although their general ambition is eminently laudable and worth struggling for, Hershkoff and Cohen's reliance on rights-talk as a means to that end is ultimately self-defeating. The dubious achievement of constitutional recognition for beggars' rights will likely increase, not reduce, the possibility that "the poor are spoken of with the kind of dehumanizing imagery that makes it possible for some to deny their existence and to expiate society from any sense of responsibility." "71 Indeed, Hershkoff and Cohen beg the very questions that they seek to answer: why are there beggars and how might we abolish them, expiate society from any real commitment to change, and not institutionalize beggars?

Accordingly, in this section of the essay, I intend to explain the seductive, but flawed and dangerous rhetoric of rights-talk to which Hershkoff and Cohen fall victim. I also will caution against its wholehearted adoption by those committed to affecting social justice for the dispossessed. While I recognize the strategic value of rights-talk, I urge the abandonment of rights rhetoric as a categoric framework for understanding and remedying social injustice. Apart from its debilitating indeterminacy, the language of rights portrays and shapes a world that is inimical to the long-term aspirations of all its citizens, especially les misérables. Giving individual rights only responds to the stark symptoms of poverty and may falsely obviate the need to confront the real structural causes of this endemic social disease. Rights-talk's abstract, universal and decontextualized depiction of individuals as moral beings undercuts the have-nots' claims to be treated as fully human, and hinders efforts to establish a more egalitarian and empowering vision of citizenship and civic justice.

The appeal and limits of rights-talk flow from the same sources. At the same time that it offers the prospect of empowering individuals and

69. See Hershkoff \& Cohen, supra note 18.

70. See id. at 912.

71. Id. at 915 . 
rescuing them from collective tyranny, rights-talk also stifles the possibility of truly progressive social change. It treats people as abstract individuals rather than as situated citizens whose lives are presently constrained as well as potentially satisfiable within existing socio-economic structures and relational contexts. Like all ways of seeing and comprehending the world, rights-talk distorts as much as it illuminates; it tends to shape the world in its own political image. Within a capitalist democracy, the use of rights-talk as a categoric mode of political argumentation suffers from two debilitating weaknesses. ${ }^{72}$ Although one is conceptual in nature and the other is ideological, they are related and mutually reinforcing. Whereas the first weakness is the ineradicable indeterminacy of rightstalk, the second is the alienating individualistic vision of social life on which it is premised.

Within the liberal vision of society, people are portrayed as rational maximizers and self-interested consumers of utilities in the neutral conditions of a market economy. There is no available metewand to make interpersonal comparisons of utility and thereby generate a plausible account of the public good. While individuals seek to obtain the maximum freedom to pursue their own self-interest, their efforts to do so require security from the subjective and selfish interference of others engaged in the same project. The central contradiction and paradox is that the more freedom with which individuals are allowed to pursue such ends, the less security they have against the intrusion of others. In short, individual freedom seems possible only through its collective limitation and negation: my freedom can only be obtained by curbing your freedom and your freedom can only be obtained by curbing mine. As an attempt at mediation, the creation of a political state is posited to replace the anarchic war of all against all with an ordered world. In order to resolve the dilemma of order-and-security, the theory of rights is enlisted to prescribe the extent and manner in which certain freedoms can be limited in order to maintain sufficient social stability and peace to allow greater freedom in general.

For such a theory to become operative, rights-talk must be capable of deriving concrete responses to particular situations from its abstract statements of principle. The history of liberal political theory and legal practice provides cogent evidence of its failure to achieve that measure of

72. It must be emphasized that this section deals only with rights-talk as a categoric mode of analysis and does not speak to the vexing question of the value of using rights-talk in a strategic manner. For a complete account of this critical rejection, see Allan C. Hutchinson \& Patrick J. Monahan, The "Rights" Stuff: Roberto Unger and Beyond, 62 TEX. L. REV. 1477 (1984). 
operational efficacy. ${ }^{73}$ Between axiom and application, there always exists in law the surreptitious exercise of power to convert general rights into particular results. As such, there is no relief from the heavy burden of choosing. Rights-talk is more effectively understood as a convenient screen of institutional propriety behind which competing interests can be accommodated and behind which the ideological choices required to effect such an accommodation can be hidden. Rights-talk is one kind of ideology, not an escape from one.

In at least five instances, rights-talk fails to provide the determinate guidance necessary to resolve the self-defined dilemma of liberal society. First, there is no non-political way of arriving at what particular group of rights are to be recognized and enforced-are socio-economic or collective rights to be included? Second, there is no uncontroversial means of determining the scope and nature of these selected rights. Does speech include advertising, flag-burning or swearing? Third, there is no neutral standpoint from which to identify who are to be the recipients of such rights. Are corporations, animals or fetuses covered? Fourth, there is no method internal to the theory of rights that can be used to adjudicate the clash of competing rights. What is the relation between liberty and equality? Fifth, the recognition that rights are fundamental, but not absolute, gives rise to the difficulty of balancing the public interest against individuals' claims. Can speech rights be exercised anywhere at any time? In all cases, rights-talk fails to ensure the operational efficacy that it promises. It also fails to be a safe methodological haven for advocates and judges in a dangerously ideological world.

In their crafted commentary, Hershkoff and Cohen give an effective and cogent demonstration of rights-talk's disabling indeterminacy. Through a dextrous and sophisticated use of normative argument and legal doctrine, they show that "begging is speech that existing first amendment values and case law protect," 74 and that it cannot be banned or unduly restricted. Of course, Hershkoff and Cohen resist the temptation to insist that this is the one and only true reading of the Constitution beyond the cavil of political expediency. Instead, they recognize the critical imperative to accept that there are other plausible and opposing interpretations that could also meet the general criteria of doctrinal fit

73. See Andrew Petter \& Allan C. Hutchinson, Rights in Conflict: The Dilemma of Charter Legitimacy, 23 U. Brit. Colum. L. Rev. 531 (1989); Allan C. Hutchinson \& Andrew Petter, Private Rights/Public Wrongs: The Liberal Lie of the Charter, 38 U. ToRonTo L.J. 278, 297 (1988) [hereinafter Private Rights].

74. Hershkoff \& Cohen, supra note 18 , at 910. 
and normative justification. Rights are a part of politics, not a precondition or boundary to the legitimate realm of contested politics. As such, Hershkoff and Cohen's argument is a compelling exercise in the progressive project of deviationist doctrinalism - the attempt to utilize routinized argumentation to transformative effect without falling into the trap of mistaking the contingently revisable for the revealed truth. ${ }^{75}$ However, the fact that the courts have not yet been persuaded by a Hershkoff and Cohen-like brief ought to tip them off to the precarious nature of their undertaking. It should not only remind them of the conservative judicial instinct to side with the established order of things, but also alert them to the ideological orientation of rights-talk that makes it more amenable to some appropriations and manipulations than to others.

\section{B. Do The Rights Thing?}

The second weakness of rights-talk flows from and reinforces the first. The predictability of rights-talk and its general political presuppositions rest upon an impoverished and partial notion of social life. It provides the institutional "means to express a tolerant market morality."76 As a historical artifact, it has played a positive role in social struggle and retains obvious strengths, such as the value of privacy, distrust of bureaucracy, and worth of rational justification. ${ }^{77}$ However, rights-talk overthrew the divine right of kings, clergy and aristocracy only to replace it with the sovereignty of the abstract individual-God in more philosophical and less theological uniform. It depicts individuals as separate and egoistic, striving for a liberty that is self-regarding and a sociability that is hollow. As such, it provides an inherently false account of human community both in its present practice and future possibilities.

Under a regime of rights-talk, society becomes little more than an aggregate of self-interested individuals who band together to facilitate the pursuit of their own uncoordinated and independent life projects, which is nothing more than a relation of strategic convenience and opportunism rather than mutual commitment and support. The very essence of individual identity is conceived of as an abstraction from its constituent connections. In this way, relations with other individuals are understood in terms of limitations rather than as vital contexts within which people can become fully human. Liberal rights-talk obliges individuals to view their connection with others and their responsibility for others as a matter of

75. See Roberto Unger, The Critical legal Studies Movement 15-22, 88-90 (1986).

76. Edward ANDrew, Shylock's Rights: A Grammar of Lockian Claims 21 (1988).

77. See Elizabeth H. Wolgast, The Grammar of Justice (1987). 
detachment and voluntary choice. There is almost a wilful refusal to recognize the extent to which people are socially situated, a failure to grasp how people shape and are shaped by their structured relations with others. The liberal account of self, adrift in society and often a stranger to itself, fails to grasp the idea and practice of oppression as group-based.

In particular, liberal theory's insistence on positing individuals as rational, self-interested and pre-social ethical beings who share little more than an abstract humanity manages to treat everyone the same, while claiming to celebrate the difference and dignity of each. It is as though everyone is a potential beggar. Even for progressive critics such as Hershkoff and Cohen, moral autonomy and democratic citizenship amount to little more than being abandoned to one's own devices and being put at the mercy of one's enabling or disabling social setting. In this way, rights-talk fails to comprehend that coercion can come in many different and subtle forms; oppression is neither exhausted by the power of the purse nor limited to the authority of the state. Within capitalist society, the category of the "abstract individual" becomes very classist in substance and orientation: rights-talk provides itself with little scope within which to recognize material deprivation and the resulting social oppression as the socio-cultural norm. Rights-talk posits an almost libertarian vision of the morally autonomous being as one committed to robust self-reliance and fierce competitiveness; the specter of the "hardworking citizen" is always in mind.

An important corollary of this informing vision of social well-being is the understanding that it is possible for beggars to alleviate their own suffering. Empowered by a suitable set of rights and fired with an earnest sense of disciplined industry, this deliverance is achievable without the rest of society having to change or sacrifice anything. Although peddled as a practically viable and eminently desirable ambition, it is really a highly objectionable and socially disingenuous vision of dystopian dimensions. Again, it places the burden on the already disadvantaged and relieves the presently advantaged from doing much at all. Furthermore, it perpetuates the pretense that the existing economic order is only a neutral backdrop against which bargaining, exchange and the accumulation of private property occur, but which itself has little impact on the nature and effects of such transactions. This, of course, is a canard. Detaching form from substance, liberalism compresses life into constricting forms and turns questions of power into a discourse of power. ${ }^{78}$

78. See Judy Fudge, The Effects of Entrenching a Bill of Rights Upon Political Discourse, 17 INT'L J. Soc. L. 445 (1989). 
A central claim made by Hershkoff and Cohen in support of a right to beg is that it can foster a sense of social solidarity and mutual responsibility that is essential for the establishment of a truly communal society: "the beggar implicitly proposes the communitarian vision in which citizens have a responsibility for each other's survival."79 As speech that engages, begging "has the ability to create social bonds between speaker and listener." 80 While the recognition of the need for solidarity is crucial, Hershkoff and Cohen's proposal is the very negation of a truly egalitarian community. The relational engagement between beggar and listener is based on the most egregious imbalance of power. It does not cultivate a "bond of empathy," 81 but perpetuates a one-sided and hierarchical relation of dependence. It arises in a plea of supplication and is consummated in an act of pity: "A squalid bargain: a human soul for a hunk of bread. Poverty offers and society accepts." 82

Rather than bridging the gulf in power between rich and poor, efforts to legitimate beggars' rights pretend that the gap can be bridged by the most impersonal and patronizing of charitable gestures. By granting formal status to the unfortunate beggar, Hershkoff and Cohen mistake the aristocratic affectation of noblesse oblige for the truly democratic spirit of communal welfare. It allows the haves to salve their troubled conscience by a conspicuous display of private charity to the have-nots. It is surely a cruel conceit to suggest that in this way beggars serve an important social function "in permitting others to discharge their religious obligation to give charity." 83 To rhapsodize the beggar in such terms is almost tantamount to asking victims of a vicious assault to feel comforted by the fact they have acted splendidly by allowing psychopaths to gratify their anti-social behavior. Surely this is the worst form of rationalization and one that does little credit to either victim or perpetrator; it is dehumanizing and demeaning. Moreover, in the mutually supportive relationship that is supposed to comprise begging, Hershkoff

79. Hershkoff \& Cohen, supra note 18 , at 902 .

80. Id. at 910 .

81. Id. at 914 .

82. Hugo, supra note 1 , at $\mathbf{1 8 0 .}$

83. Hershkoff \& Cohen, supra note 18, at $900 \mathrm{n} .18$. They compound this difficulty by arguing that "the beggar nonetheless feels himself at an advantage, because the more fortunate need him as an object of charity." Id. (quoting MARK ZBorowski \& ElizabeTh Herzog, Life Is with PeoPLE: The Culture of THE ShTETL 211-12 (1952)). This is surely a perverse inversion of the moral hierarchy. 
and Cohen's fixing of moral and cultural stigma on the listener is perversely misascribed: "[t]he soul in darkness sins, but the real sinner is he who caused the darkness." 84

Hugo would have had the measure of such intellectual charity and naivete. In a hard-hitting scene, he demonstrates the sublimated anger that beggars feel toward their benefactors. The vile Thenardier is masquerading as a pitiable Fabantou, a dramatic artist fallen on hard times. In what turns into a fateful meeting, he is visited by the philanthropic Monsieur Leblanc, who is none other than the elusive Jean Valjean. Although Thenardier is a conniving and thoroughly bad lot, his thoughts on the self-righteousness of the charitable rich are pertinently tart. He understands full well that philanthropy is not what the dispossessed want, but what they despise:

Oh, God, how I hate them! I'd like to strangle the lot of 'em, the rich, the so-called charitable rich, living in clover and going to Mass, and dishing out sops and pious sentiments. They think they're our lords and masters and they come and patronize us and bring us their cast-off clothes and a few scraps to eat. Bastards! That isn't what I want. Money's what I want, and money's what they never give us. They say we'll just spend it on drink, and that we're all sots and loafers. And what about them? Where did they spring from for God's sake? Thieves, that's what they were, otherwise they'd never have got rich. I'd like to take the whole blasted works and stand it on its head. Perhaps everything would get smashed up, but at least it would mean that everybody would be in the same boat and we'd be that much to the good ...85

On the issue of begging, contemporary America finds its Monsieur Leblanc in the scholarly guises of Helen Hershkoff and Adam Cohen. By institutionalizing and legitimating the position of "beggar," Hershkoff and Cohen do les misérables the considerable disservice of entrenching the fact of poverty rather than working to eradicate it. The most that begging does is to provoke charity, often generous, but it in no way changes the general situation that permits and often condones the poverty that begets the beggar. These destitute souls beg not for alms, but for an end to their plight as helpless hostages to capitalist fortune. It is public transformation they seek, not private charity.

Like most rights in the liberal vocabulary, the right to beg is formal and not substantive. Admittedly, begging helps to counteract the view

84. Hugo, supra note 1 , at 30 .

85. Id. at $647-48$. 
that "poverty in America is either non-existent or insignificant"86 and "makes it impossible for [mainstream listeners] to be oblivious to the poverty in their midst," 87 but it fails to generate any substantive response by way of a corollary right or otherwise. ${ }^{88}$ As a kind of speech, it is fully satisfied by permitting individuals to give voice to their complaints, but without any obligation on listeners to make any substantive response to those pleas. It depicts a just society as one in which the achievement of moral autonomy can be affected without concern for serious economic equality. Indeed, taking seriously the idea of a right to beg confirms that, in contemporary society, property still remains the measure of all things. Without property, beggars are barely people: they are almost nothing, because they own almost nothing. Echoing the sentiments of the nineteenth century industrial elite, the vast majority continue to believe that all human beings have a real existence only if they make money or help to make it. ${ }^{89}$

It is crass to talk of a person's self-realization in circumstances in which "she is destitute and needs help." 90 To speak in such terms is to fall victim to the idealist temptation to treat freedom as a purely metaphysical state of mind; people can be free even in the most dire of material conditions, provided that they have the liberty to think and speak for themselves. It is a pretense of the privileged to talk of agency in such circumstances. This amounts to the violence of abstraction and is the philosophical kissing-cousin of rights-talk in the dysfunctional family of liberalism. ${ }^{91}$ Such political theorizing commits a grievous form of intellectual harm that gives fraudulent legitimacy to the content and consequences of contemporary living.

86. Hershkoff \& Cohen, supra note 18 , at 898 .

87. Id. at 912 .

88. It is tempting to propose a litigation strategy that strives to establish something like a right to private property. There are many interesting and suggestive proposals for such tactics. See JERemy Waldron, The Right to Private Property (1988); Singer, The Reliance Interest in Property, 40 STAN. L. REv. 611 (1988). However, the response of the courts to such claims has been less than encouraging. See Dandridge v. Williams, 397 U.S. 471 (1970). Moreover, there are other more viable and less risky avenues of struggle open to progressive lawyers.

89. See Frederick Engels, The Condition of the Working Class in England 311 (W.O. Henderson \& W.H. Chaloner eds. \& trans., 1958).

90. Hershkoff \& Cohen, supra note 18, at 903.

91. Derek Sayer, The Violence of Abstraction (1987); see also John Rawls, A TheORY OF JUSTICE (1971). Even most liberal theorists concede that to talk of "moral agency" in conditions of abject poverty is nonsensical. 


\section{THE PROGRESSIVE AGENDA}

Progressive and non-progressive critics have failed to show that the performance of the courts in fulfilling their political responsibilities has met the exacting standards of constitutional legitimacy and justice. It cannot claim to be a purely objective exercise in legal justification, to supply the necessary level of operational determinacy, or to result consistently in progressive contributions to political life. Indeed, as the institution of judicial review moves into its third century, evidence mounts and supports a skeptical view of the courts' inherent incapacity to enhance or reconstruct the democratic quality of the American polity. Benignly misguided or more sinisterly intended, the performance of the judges has been largely conservative. There is little evidence to support a more optimistic prognosis. ${ }^{92}$ Yet, rather than dwell on these failings and indulge in a cynical smugness, $I$ believe that the time has come to be more constructive. This can be achieved by concentrating on the political ambitions that unite the academic combatants rather than on the intellectual affiliations that divide them. As Rome burns, it does little credit to anyone to stand idly by and take comfort in pointing out that the city's fire fighters are using oil in the mistaken belief that it is water.

Accordingly, progressive scholars must look for better and different ways to empower disadvantaged groups and to improve litigation of constitutional rights. In criticizing the political wisdom of striving to establish a right to beg, I have suggested that the pressing issue is not whether such a right can be doctrinally justified, but why such efforts are warranted and what practical effect the recognition of such a right will have on the larger progressive struggle to replace the capitalist economy. In this section of the essay, I want to propose a more compelling account of moral self-realization and a more constructive route to political enlightenment, one that better appreciates and incorporates the politically-situated and socially-oriented relational character of democratic governance.

In effecting such a proposal, two steps must be taken. The first step is to raise the critical consciousness of lawyers by disabusing them of their ingrained habit of resorting to the courts as the transformative forum of choice. They must become more sensitive to the debilitating effect of the extended involvement of courts in civic life. Secondly, progressive lawyers must develop a posture of "strategic skepticism" toward

92. See Mark Tushnet, The Red, White and Blue (1988). 
the efficacy of even limited use of litigation in the struggle for social justice. To direct the have-nots to the courts as a matter of course is, in a pertinent manner of speaking, to throw good money after bad.

\section{A. Shades of BRown}

The key issues for those devoted to improving the lot of les miserables are to determine what substantive changes will best achieve that objective, how those measures can best be implemented, and which institutions can best carry out that agenda. The details and priorities of progressive politics must be the continuing subject of healthy debate and respectful disagreement. There is no place for an enforced orthodoxy or rigid conformity because "a just society is not a society that has adopted just laws, once and for all, rather it is a society where the question of justice remains constantly open." 93 While there must be a willingness to utilize diverse strategies to effect progressive change and to resort to a variety of institutional sites, such tactical calculations need to be sensitive to the prevailing realities of social power and economic ordering. The history of social struggle strongly suggests that the courts are not institutionally or ideologically congenial to such efforts. The prospect of significant social change through litigation is, as Judge Jackson aptly put it, "a teasing illusion like a munificent bequest in a pauper's will." ${ }^{94}$

The life of Linda Brown is emblematic of the courts' congenital defects as an arena for social change. In 1950, she was a young girl in the town of Topeka, Kansas attending a segregated elementary school for black children. Her father, Reverend Oliver Brown, raised a constitutional challenge to the arrangement. On May 17, 1951, the Supreme Court handed down its decision that declared state-enforced segregation of public schools to be unconstitutional. ${ }^{95}$ Hailed as a momentous decision, it was and still is treated as having struck a definitive blow on behalf of racial justice. Indeed, Thurgood Marshall, Brown's leading lawyer, was convinced that as a result of the Court's decision, segregated schools were a thing of the past, and that in under ten years, segregation in all its forms would be eliminated from the nation. ${ }^{96}$ However, Linda Brown's life changed little. In 1979, a full twenty-five years after Brown, she joined a challenge against the same Topeka educational system claiming that her children were prejudiced by the still racially segregated

\footnotetext{
93. Cornelius Castoriadis, Socialism and Autonomous Society, 43 Telos 91, 104 (1980).

94. Edwards v. California, 314 U.S. 160, 186 (1941).

95. See Brown v. Board of Educ., 347 U.S. 483 (1954).

96. N.A.A.C.P. Sets Advanced Goals, N.Y. Times, May 18, 1954, at 16.
} 
schools. ${ }^{97}$ Ten years later, in December, 1989, the Court of Appeals for the Tenth Circuit held that Topeka had not taken sufficient steps to ensure that black children did not receive education inferior to that of white children. ${ }^{98}$

The frustrating experience of Linda Brown stands in cruelly stark and sadly ironic contrast to the almost euphoric reception that the Brown decision still receives in elite legal and academic quarters. ${ }^{99}$ The overwhelming orthodoxy is that adjudication has always been important to society and amounts to a socially significant institution. The prevailing belief seems to be that adjudication produces a clear and direct effect on the litigants' personal situation and brings about the judicially contemplated and intended change in the litigants' future relations. Furthermore, adjudication does not affect only the litigants. Although there will be some distortion, judicial decisions tend to have a ripple effect. Like a stone dropped into water, adjudication creates waves on the social pond; their intensity and impact lessen as they travel further from the local epicenter of the dispute. In short, there is a quaint and simplistic instrumentalism at large.

The problem with this sanguine scenario is that there is very little empirical support for such extravagant and imperialistic claims. ${ }^{100}$ of course, the task of confirming or confounding these instrumental assumptions is fraught with difficulty. Not only is there a paucity of serious study and analysis, but the subject does not lend itself to facile inquiry. Any judicial current injected into the social body must immediately contend with the buzzing grid of forces already at work in society. The judicial current might combine with other forces and either be completely overwhelmed and neutralized, or be the institutional straw that breaks the social camel's back. On the other hand, the judicial impulse might be sufficiently strong and well-directed that it will act in such a manner as to effect a discrete and lasting change in social behavior. However, the seduction of blunt or hasty conclusions should be avoided. Judicial decisions are neither always nor never an influential factor in social change. In the most comprehensive and exhaustive survey of the

97. See Brown v. Board of Educ., 84 F.R.D. 383 (D. Kan. 1979).

98. See Brown v. Board of Educ., 892 F.2d 851 (10th Cir. 1989), cert. granted and judgment vacated, 112 S. Ct. 1657 (U.S. Apr. 20, 1992), opinion reinstated by, 978 F.2d 585 (10th Cir. 1992), reh'g denied (Jan. 28, 1993).

99. See, e.g., Ronald Dworkin, Law's Empire 2 (1986) (Brown "took the nation into a social revolution more profound than any other political institution has, or could have, begun.").

100. See Laurence H. Tribe, God Save This Honorable Court 111, 139-40 (1985) (new judicial appointments change direction of the Court). 
field, Gerald Rosenberg is firmly of the opinion that "courts can almost never be effective producers of significant social change."101 At best, the courts' impact is so subtle that it is difficult to isolate. As such, the onus is upon the proponents of the conventional view to ground their instrumental assumptions.

Judicial victories are hard-won and do not convert easily into effective social change. Apart from their ideological leanings, the courts lack the resources or instruments to orchestrate such wholesale transformations. Possessing control over neither purse nor sword, ${ }^{102}$ the judicial capacity is limited and is better suited to highlighting the discrepancy between social action and social ideals than to taking affirmative steps to close that gap. Being reactive, the judicial branch of our government is better suited for blocking and delaying change. ${ }^{103}$ Moreover, legal victories may misleadingly signal social success and con people like Thurgood Marshall into believing that the end is in sight and almost in reach. Winning of the litigation battle is not always a reliable indicator of the ultimate victor in the broader social war. Judicial success can dissipate in the face of larger unsympathetic social forces and judicial failure can be turned to social advantage. De jure results do not always correlate with de facto outcomes.

Like modern medicine, litigation tends to be pathological and piecemeal in nature; it treats individual symptoms rather than structural causes. Despite some recent realignment, courts still view themselves as best suited, by tradition and expertise, to deal with one-shot, discrete, two-party disputes, capable of being remedied by a transfer of money. However, rights litigation for social change challenges this paradigm as it moves away from it. The problems that it addresses are much more amorphous and public and the solutions that it seeks are much more prospective and quasi-legislative. Remedial administration is a continuing affair and there is not a dispute between private individuals about private rights, but a grievance about the operation of public policy. ${ }^{104}$ To adjust to such disputes, not only must the courts rethink the parameters of their institutional competence, but they must effect a dramatic change

101. Gerald N. Rosenberg, The Hollow hope: Can Courts Bring about Social Change? 338 (1991).

102. The Federalist No. 78, at 465 (Alexander Hamilton) (Clinton Rossiter ed., 1961). But see Gerald E. Frug, The Judicial Power of the Purse, 126 U. PA. L. Rev. 715 (1978).

103. Cf. Arnold M. Paul, Conservative Crisis and the Rule of Law: Attitudes of BAR AND BENCH, 1887-1895 (1960) (recalling judicial hostility to economic regulation).

104. See Abram Chayes, The Role of The Judge in Public Law Litigation, 89 HARv. L. Rev. 1281,1284 (1976). 
in their willingness to experiment with imaginative injunctive schemes of relief. Even if the judicial spirit was willing, the institutional flesh is too weak.

Notwithstanding this incipient shift in response and orientation, the courts focus their therapeutic efforts on individual behavior. Litigation is most effective where a "negative order" (i.e. one requiring somebody to refrain from action) is sought against a non-bureaucratic entity in a discrete dispute that can be implemented by a simple administrative directive. However, if there is to be real, lasting and significant social change, there must be a transformation of institutional structures and social practices. Yet, it is in these very circumstances-continuing disputes with a large bureaucratic organization, public or private, that require compliance by front-line officials, such as the police or welfare officials-that courts are most reluctant and impotent to effect change. Bureaucratic intransigence and complexity often block court-enforced change. Accordingly, the best that can be expected from judicial institutions is that their effects on social behavior and attitudes will be "incremental, gradualist, and moderate." 105 This predicament and prognosis is best evidenced and supported by the subsequent history of Brown.

Contrary to the conventional view that Brown marks the legal beginning of the social end to the American system of apartheid, the popular drive to overcome racism began before 1954. The impact of the Supreme Court's decision is contestable and attenuated. Initially, little change occurred in the Southern states, official compliance was sporadic, and judicial decrees routinely were ignored. ${ }^{106}$ Only when the other branches of government, with the powers of purse and sword, became involved by passing the Civil Rights Act of 1964 was action taken. While one might surmise that Brown acted as a catalyst for congressional or presidential initiatives, there is little data to confirm such an assessment. Nor is there any convincing empirical evidence that Brown was the spark that ignited the black population in a blaze of racial revolution. While the Supreme Court's decision may have had a significant effect on black civil rights leaders, ${ }^{107}$ ordinary black people remained not-so-blissfully ignorant of their so-called liberation.

105. Joel F. HANDler, Social Movements and THE Legal System: A Theory of LAW REFORM AND SOCIAL CHANGE 233 (1978).

106. G. Theodore Mrtau, Decade of Decision: The Supreme Court and the ConstlTUTIONAL REVOLUTION 1954-1964, at 60-78 (1967).

107. See Eldridge Cleaver, Soul on ICE 3 (1968). 
Paradoxically, Brown may have actually hardened resistance and delayed change, although this conservative backlash might itself have mobilized deeper forces of change. The legal obligation of government to dismantle institutional racism made no significant contribution to parents' decisions to avoid school desegregation; it had more to do with the size of black enrollment and the parental capacity to finance private education. ${ }^{108}$ It might well be the case that Brown reflected, but did not create, a momentum for change, and that only "when political, social and economic conditions have become supportive of change, courts can effectively produce significant social reform." 109

\section{B. Critical Consciousness}

Those committed to serious social change must not forget that what is important is not the effect of a particular piece of constitutional litigation, but the very existence of the whole adjudicative process as a privileged mode of social action. In short, constitutional litigation and adjudication are special social activities that do not so much cause or change, but comprise and are constitutive of extant social conditions: "[It] is not so much that the court is the natural expression of popular justice, but rather that its historical function is to ensnare it, to control it and to strangle it, by re-inscribing it within institutions which are typical of a state apparatus." 110 To participate in the litigation process as lawyer or litigant, however radical the claim or cause, is to challenge existing social relations: Litigation may reinforce or alter the status quo. As a result, constitutional litigation and adjudication may hinder rather than enhance social change and entrench rather than overthrow the dominion of the established order.

As such, it is dangerously naive and overly romantic to contend that court-enforced rights can, will, or should be the preferred medium for the social activist. The self-serving conceit of lawyers causes them to encourage the continued use of litigation as a constructive and viable route to social justice. As a purely pragmatic matter, history has little encouraging to say. The language of the law often has been and continues to be the language of the poor's misery. While, as a practical and instrumental matter, it is difficult to challenge subordination within and through the very institutions that subordinate people, there is also the

108. See Michael W. Giles \& Douglas S. Gatlin, Mass-level Compliance with Public Policy: The Case of School Desegregation, 42 J. PoL. 722 (1980).

109. ROSENBERG, supra note 101 , at 31.

110. Michel Foucault, Power/Knowledge 1 (Colin Gordon ed. \& trans., 1980). 
political and ideological grip that judicial discourse places on its participants. As I have tried to demonstrate in deconstructing the rhetoric of poverty, the law presents and posits a reality that is partial in its values and meanings: "[T]he legal forms we use set limits on what we can imagine as practical outcomes." 111

Throughout Les Misérables, law is one of the powerful and dark forces that holds in place the social conditions that amount to a living hell for many. In the enormous struggle between good and evil, law stands as the manifestation and might of the established order. The personnel of the law are reviled, not revered. Indeed, Marius turns away from his chosen career of advocate because "[t]he thought of consorting with attorneys, hanging about the courts, chasing after briefs, was odious to him."112 For Hugo, the court is a place to be avoided and lawyers are people to be chastised:

The sight of these groups of black-robed gentlemen murmuring together on the threshold of a court of law is always a chilling one. Little charity or compassion emerges from their talk, which is principally concerned with guessing which way the verdict will go. They are like clusters of buzzing insects absorbed in the construction of dark edifices of their own. ${ }^{113}$

This general sentiment of ill-will to law and lawyers festers throughout the novel, but erupts and is given full vent in several crucial incidents. By way of setting the theme and tone of the book, Hugo begins with the cruel tale of Jean Valjean's imprisonment. At 24, orphaned, impoverished and supporting his widowed sister's family of seven, he is found guilty of stealing a loaf of bread and sentenced to five years of hard labor. Valjean's fate is used to epitomize the terrible cruelty of the law which "decrees the wrecking of a human life ... and consigns a sentient being to irrevocable abandonment." 114 Like Jean Valjean, Young and Walley were ground between the millstones of social neglect and legal attention: their crime was more society's than their own. While their punishment was less ferocious and outrageous than Jean Valjean's, Young and Walley are entitled to be equally outraged at the imbalance between the wrong allegedly done by them and the wrong inflicted upon them by the law. For all three, law is the object of their outrage and a cause of their misery. Society had concerned itself with them only to castigate them further. To the pain caused by the indifference of social

111. Robert W. Gordon, Critical Legal Histories, 36 Stan. L. REv. 57, 111 (1984).

112. Hugo, supra note 1, at 591.

113. Id. at 240 .

114. Id. at 93. 
conscience was added the indignity brought about by the solemnity of legal sanction:

Was he the only one at fault in this fateful business? Was it not a serious matter that a man willing to work should have been without work and without food? ... Was not the law more at fault in the penalty it inflicted than he had been in the crime that he committed? Had not the scales of justice been over-weighted on the side of expiation? And did not this weighting of the scales, far from effacing the crime, produce a quite different result, namely, a reversal of the situation, substituting for the original crime the crime of oppression, making the criminal a victim and the law his debtor, transferring justice to the side of him who had offended against it? ... Was it not monstrous that society should treat in this fashion precisely those least favored in the distribution of wealth, which is a matter of chance, and therefore those most needing indulgence? ${ }^{115}$

Nevertheless, while it is crucial not to exaggerate the contributions of the court, it is equally important not to overstate the democratic qualities of representative institutions or to deny entirely the possibility that legal forums could contribute to transformative struggle. Lawyers are not always and only "the goon squad of the ruling class."116 As the pervasive conversational idiom of modern society, it is difficult not to participate in the stylized conversation of rights-talk in any attempt to challenge existing arrangements and to improve the lot of ordinary people. But to join that conversation imposes a great risk of being co-opted and becoming vulnerable to takeover. Nevertheless, the fear of co-option must not lead to paralysis. It is neither impossible nor imprudent to adopt the use of traditional rights litigation as a limited strategy in the radical practice of law: the categoric denial of rights-talk is almost as bad as its categorical embrace. Between addiction and abstinence lies the considerable expanse of mindful moderation.

In efforts to transform law and society, a sensitivity to the contingent possibilities of any particular moment in social history is important. A close attention to contextual detail is vital. In particular historical conditions and social circumstances, rights-talk might not be entirely without utility. However, its use must be informed, guarded and clearheaded; there is no room for romantic attachment. It must be used with a caution that comes with the realization that it can as easily harm as do

115. Id. at $96-97$.

116. David A. Price, Taking Rights Cynically: A Review of Critical Legal Studies, 48 CAmBRIDGE L.J. 271, 272 (1989); see also Patrick Macklem, Of Texts and Democratic Narratives, 41 U. TORONTO L.J. 114 (1991). 
the bidding of its user. Some of the right questions to ask about rights are posed by Elizabeth Schneider:

Does the use of legal struggle generally and rights discourse in particular help build a social movement? Does articulating a right advance political organizing and assist in political education? Can a right be articulated in a way that is consistent with the politics of an issue or that helps redefine it? Does the transformation of political insight into legal argumentation capture the political visions that underlie the movement? Does the use of rights keep us in touch with or divert us from consideration of and struggle around the hard questions of political choice and strategy? ${ }^{117}$

The pivotal difficulty with rights litigation is that it is based on the mistaken premise that the state is the major threat to citizens' freedom and the single source of institutional oppression. Of course, the state has an almost unparalleled potential for oppression and has often used it to disreputable ends. However, to concentrate exclusively on the state fails to recognize the extent to which private centers of power exert at least as great an effect on the quality of people's lives as any function of official authority: the state may be the only friend of the disadvantaged. Such a state-citizen focus distorts the multiple and diffuse abuses of power that constitute the social experience of domination. This ideological underpinning of rights-talk becomes particularly significant and stultifying when it is combined with the fact that the thrust of litigation is the individualized attribution and remodification of fault: there is little attention to the structural composition of injustice and the institutional limitations of judicial remedies. ${ }^{118}$

Ultimately, any gain through litigation will serve to lend popular credence to the legal system as a legitimate arena for successful transformative activism. To engender respect for any rights gained and to ensure their effective enforcement, it will be necessary to instill a general reverence for the courts as a whole. ${ }^{119}$ While such a strategy might allow small advances to be made, it will actually defer and inhibit the kind of profound changes necessary for truly progressive transformation: minor improvements are the obstacles, not the precursors to major innovation.

117. Elizabeth M. Schneider, The Dialectic of Rights and Politics: Perspectives from the Women's Movement, 61 N.Y.U. L. REv. 589, $622-23$ (1986).

118. See Kristin Bumiller, The Civil Rights Society (1988); Alan D. Freeman, Legitimizing Racial Discrimination Through Antidiscrimination Law: A Critical Review of Supreme Court Doctrine, 62 MINN. L. REv. 1049 (1978).

119. See Harry J. Glasbeek, Some Strategies for an Unlikely Task: The Progressive Use of Law, 21 OTTAWA L. REv. 387, 396 (1989). For an illustration of this point in the context of Roe, see infra part IV.C. 
For instance, when talking of small skirmishes and minor revolts, Hugo contrasts this to large-scale insurrections. He suggests that, while such acts may inspire "those it lays hold of with extraordinary and mysterious powers, raising everyman to the level of events," 120 such restrained uprisings may serve best the interests of those in power:

[I]n principle any revolt strengthens the government it fails to overthrow. It tests the reliability of the army, unites the bourgeoisie, flexes the muscles of the police, and demonstrates the strength of the social framework. It is an exercise, almost a course of treatment. Power feels revived after a revolt, like a man after a massage. ${ }^{121}$

Moreover, small victories carry their own considerable price tag. Being abstract and potentially universalistic, rights-talk has no necessary political content and application: rights-talk is a site for struggle and occupation, not a completed project. Consequently, any right that is achieved cannot be controlled in its precise definition or utilization. It can be ambushed and held hostage by non-progressive lawyers and turned to the advantage of their own (privileged) clientele. Indeed, this is exactly what has happened in Canada. In the first three years after the introduction of the Charter of Rights and Freedoms's equality provision, there were approximately 600 court decisions of which forty-four decisions, or seven percent, involved sexual equality. ${ }^{122}$ Most alarmingly, only seven of these cases were initiated by or on behalf of women; the other thirty-seven decisions were based on claims by men. ${ }^{123}$

Mindful, therefore, that established interests have greater access to courts and greater normative rapport with judges, one must realize that the likelihood of systemic defeat being snatched from the jaws of a rights victory is not small. The corporate takeover of the First Amendment is a stunning example in point. ${ }^{124}$ As Young itself clearly shows, not only have corporations been able to reap considerable substantive protection, they have also managed to manipulate the rhetorical agenda so that their

120. Hugo, supra note 1 , at 884 .

121. Id.

122. Gwen Brodsky \& Shelagh Day, Canadian Charter Equality Rights For WOMEN: ONE STEP ForwARD OR Two STEPS BACK? 10-25 (1989). Nevertheless, Brodsky and Day still believe that the problem has been primarily doctrinal. For skeptical critiques, see Judy Fudge, The Public/Private Distinction: The Possibilities of and the Limits to the Use of Charter Litigation to Further Feminist Struggles, 25 Osgoode HaLl L.J. 485 (1987); Brenda Cossman, Dancing in the Dark, 10 Windsor Y.B. OF ACCESS To JUST. 223 (1990) (reviewing Brodsky and Day).

123. BRODSKY \& DAY, supra note 122, at 23.

124. See Mark Tushnet, Corporations and Free Speech, in THE Politics of LAw: A ProgresSIVE CRITIQUe 253 (David Kairys ed., 1982); HutChinson, supra note 12, at 169-78. 
interests receive primary doctrinal consideration. The courts act cautiously when corporate concerns are implicated and, even when dealing with non-corporate issues, they succeed in underlining the centrality of corporate speech to the First Amendment paradigm. How else is it possible to understand a judicial mindset that fails to see the conceptual connection between corporate advertising and charitable solicitations such that the former receives constitutional protection and the latter does not? ${ }^{125}$ Clearly, rights-talk is the kind of constitutional conversation to be avoided by the progressive activist.

\section{Strategic SKePticism}

Imbued with an appropriate sense of critical consciousness, the most encouraging course for progressive lawyers to follow is to develop a selfconscious program of strategic skepticism. Such a program would be more the cultivation of a particular mindset and the refinement of various tactical techniques than the establishment of a manifesto of litigable claims. The core idea is to act in a guerilla-like way, within a broad set of progressive objectives, to seize the possibilities of any contingent moment in order to achieve judicial decisions that heighten the status quo's contradictions and open up space for lasting political action. It is imperative in pursuing such legal tactics that lawyers do not become intoxicated by the spirit of their own rhetorical excesses. To take the reasoning of judges seriously is to validate once again the very institution that is to be subverted: it is to fall victim to the contagion of traditional jurisprudence in which law thrives as a rational enterprise of abstract politics. The progressive lawyer must forsake such comforting platitudes and remember that "the best we can do, as lawyers, is to raise consciousness about the way law and its functionaries have helped create a hegemony which the inequality in our polity makes look natural."126

The situation that best exemplifies the benefits and risks of "strategic skepticism" is the abortion litigation. The victory in Roe v. Wade ${ }^{127}$ brought bright rays of progressive sunshine into the long and drab wintry days of constitutional litigation. Yet it is vital not to forget what it is that is being celebrated and why it occurred. Eugene Rostow and Alexander

125. See supra part II.B.

126. See Glasbeek, supra note 119 , at 411 .

127. 410 U.S. 113 (1973). 
Bickel may have been right in casting the Supreme Court as an educational institution. ${ }^{128}$ However, while it is undoubtedly true that the Supreme Court's decision offered a public occasion for civic instruction, the best democratic lessons are invariably overlooked or ignored. Indeed, Roe and its aftermath might well be viewed as a national seminar in the efficacy of constitutional litigation and judicial review as forms of political activism. As perennial members of les misérables, the suffering of men pales before "the abjection of women." 129 Some of the lessons to be learned include the questionable instrumentality of judicial decisions in social change, the continuing capacity of judges for vacillation, the inhospitability of rights-talk to progressive claims, the need for disruptive litigation tactics, and the dangers of litigation success.

As a matter of public discussion, abortion is constantly thought about but never thought out. The debate is as old as society itself and promises to continue for generations to come. In recent decades, the engagement has shifted to the courts. Rather than bring clarity, order, and restraint to this perennially contested topic, law has tended to exacerbate the tensions and differences among the protagonists. Indeed, the debate over the legality of and permissible limits on abortion is a classic example of legal argument: everybody talks, but few listen; everybody has an opinion, but few agree; much is said, but little is accomplished. Despite the contributions of numerous scholars and lawmakers, ${ }^{130}$ the issue remains unresolved, and is likely to be unresolvable to everyone's satisfaction. However, the more limited focus of my attention is on the extent to which the courts proved to be a beneficial forum for progressive social change.

The first thing to be noted is that Roe was neither the victory that pro-choice supporters wanted it to be nor the defeat that the anti-abortionists feared it would be. The decision of the Supreme Court was no more (and no less) than another move in the play of social policy. Indeed, available statistics and more informed opinions show that the Supreme Court simply followed and approved changes that had already

128. See Eugene V. Rostow, The Democratic Character of Judicial Review, 66 Harv. L. REv. 193, 208 (1952); Alexander Bickel, The Least Dangerous Branch: The Supreme Court AT THE BAR OF Politics 26 (1986).

129. HUGO, supra note 1 , at 638 .

130. See, e.g., Laurence H. Tribe, Abortion: The Clash of Absolutes (1990); Gilbert Y. Steiner, The Futility of Family Policy 51 (1981); Catharine A. Mackinnon, FemiNISM UNMODIFIED: Discourses ON LIFE AND LAW $93-94$ (1987). 
occurred. ${ }^{131}$ In the six years prior to the Supreme Court's decision, there was a much greater increase in the number of abortions than after the decision: the rise in abortions after 1973 merely continued an existing trend. ${ }^{132}$ As such, Roe allowed the social forces in play to continue in effect; it did not start or accelerate the trend. ${ }^{133}$ The greatest impact has not been on the number of abortions, but, rather, on the number of illegal abortions that are performed. The Supreme Court's decision brought abortion out of the criminal shadows and into the public light of day. Nevertheless, while this result is to be applauded, the decision in Roe did little to reduce continuing local obstacles to abortion. Women who had difficulty in obtaining abortions before 1973 still experienced the same difficulties after $1973 .{ }^{134}$

Indeed, Roe may well have coalesced and galvanized opposition to abortion by providing a convenient focus for anti-abortion groups and conservative forces. Contrary to some progressive hopes, the case may not have exercised moral leadership on an equivocating nation. A flurry of legislative proposals were made at the federal and state levels. For instance, within three years of Roe, thirty-two states had passed legislation which sought to restrict or regulate access to abortions. ${ }^{135}$ In the twenty years since Roe, courts have been backsliding on their commitment to women's rights to reproductive freedom. While the Supreme Court has not overruled Roe, it has allowed both the denial of Medicaid funding for abortion services, ${ }^{136}$ and the required provision of anti-abortion counseling. ${ }^{137}$ This speaks to deeper problems with a reliance on rights-talk.

Apart from its debilitating indeterminacy, the abstract, decontextualized, and universal language of rights portrays and shapes a world that

131. See Julie Conger, Abortion: The Five-Year Revolution and Its Impact, 3 EcologY L.Q. 311 (1973); Thomas G. Moyers, Abortion Laws: A Study in Social Change, 7 San Diego L. Rev. 237 (1970).

132. See Edward Weinstock et al., Abortion Need and Services in the United States, 1974-1975, 8 Fam. Plan. Persp. 58, 58 (1976); Rosenderg, supra note 101, at 178-201.

133. Even a committed instrumentalist like Choper admits that the Supreme Court might have been riding a tide of established social change. He contents himself with the conclusion that, at least, the Roe decision "greatly hastened the drive toward abortion legalization." Jesse $\mathrm{H}$. Choper, Consequences of Supreme Court Decisions Upholding Individual Constitutional Rights, 83 MicH. L. REv. 1, 189 (1984).

134. See Stanley K. Henshaw et al., Abortion Services in the United States, 1984 and 1985, 19 Fam. Plan. Persp. 63 (1987).

135. See Joseph P. Witherspoon, The New Pro-Life Legislation: Patterns and Recommendations, 7 ST. MARY's L. J. 637, 646 (1976).

136. See Harris v. McRae, 448 U.S. 297 (1980).

137. See City of Akron v. Akron Ctr. for Reprod. Health, 462 U.S. 416 (1983). 
is inimical to the long-term aspirations of women to be treated as fully human. Moral autonomy amounts to little more than being abandoned to one's own devices and being put at the mercy of one's enabling or disabling social setting. This sense of non-attachment "is not the way women generally think about themselves and is utterly inappropriate as a description of a woman who is pregnant."138 Within liberal society, the category of the "abstract individual" becomes very patriarchal in substance and orientation: rights-talk provides itself with little scope within which to recognize women as members of oppressed groups, or male hegemony as the socio-cultural norm. Not only does liberalism posit a male vision of the morally autonomous being as one committed to robust self-reliance and fierce competitiveness, it manages to assume that reproduction and child-rearing will take care of themselves. As such, liberal theory offers women a Hobson's choice: they must deny that an important part of their moral and social distinctiveness derives from their reproductive capacities if they are to obtain full moral standing, or they must reduce themselves entirely to their reproductive identities and become dependent second-class citizens, trapped within the confines of their own biological distinctiveness. ${ }^{139}$

Another feature of a Roe-like right is its negative aspect. In contrast to Brown, any instrumental success of Roe may have been because the complainants' requested remedy was more suited to the courts' traditional self-image; they asked for state withdrawal and not state interference. However, the very arguments that are used to ground and police the woman's right to choose an abortion handcuff its proponents' and the courts' ability to develop and substantiate that right. There are very definite and conservative limits to rights that are based on a "keep the state out" philosophy of moral action and choice. Freedom is more than a

138. Donna Greschner, Abortion and Democracy for Women: A Critique of Tremblay v. Daigle, 35 MCGILL L.J. 633, 652 (1990); see also Robin West, Jurisprudence and Gender, 55 U. CHI. L. REV. 1 (1988).

139. Similarly, an acknowledgement of social realities undercuts many of the abortion opponents' arguments. They claim to root their convictions in respect for the sanctity of human life, but the life that they seek to protect would seem to begin at conception and end at birth. This narrow vision inexcusably ignores the fact that denial or access to safe abortion services will put the lives of countless women in jeopardy. Prohibiting or restricting reproductive choice, while adequate day care and social support services continue to be denied to women, will not eradicate the need or desire for abortion. Rather, it will compel beleaguered and poor women to once again risk septicemia and death at the hands of unscrupulous back-street butchers. A return to those dark ages would be a sad legacy. See Lisa Fishbayn \& Allan C. Hutchinson, Slouching Toward Gilead: Rights-Talk and Abortion (1990) (unpublished manuscript, on file with the Southern California Interdisciplinary Law Journal). 
lack of collective interference; it is the establishment of positive opportunities for substantive action. A more positive and less rights-oriented vision of social justice would not be premised on liberty as negatively defined, but would look to the state to stand by and empower women so that they would have the true autonomy to make decisions for themselves, have those decisions respected, and work toward providing the social conditions and institutional resources to give effect to those decisions. In short, the more pressing challenge is to establish a social life in which the need to choose abortion would be greatly reduced-a world in which women could be equally and fully human. ${ }^{140}$

The negativity of rights-talk results from the liberal insistence on dividing the world into public and private spheres. ${ }^{141}$ The courts are constrained to view the state as a potential source of oppression and to treat the private realm as a sphere of freedom. While the state can be a culprit, victims often suffer oppression at the hands of private actors and through structures of private power. On questions of abortion, the courts still cling to a strict and inappropriate division of social life in the public and private realms. As the Supreme Court so succinctly expressed in Harris, "although government may not place obstacles in the path of a woman's exercise of her freedom of choice, it need not remove those not of its own creation."142 Such platitudes only add insult to injury. Women can only get an abortion if they can find a doctor to do it and have the financial resources or funding assistance to pay. Without adequate resources or funding, abortion remains accessible only to the privileged. In such circumstances, a putative right to an abortion is cold comfort. Again, those who comprise les misérables do so because of personal failings and not through any systemic fault with the polity. As Rhonda Copelon summarizes it:

To treat a woman's poverty and her inability to exercise choice as a consequence not of public policy but of private fault is an erroneous and dangerous fiction built upon the traditional separation of the public and private spheres. It rests on the idea, central to capitalist patriarchy, that the family unit has the responsibility of being economically self-sufficient. Not only does privatization permit the state to escape responsibility for the tragic conditions of people's lives. The ideology

140. See Brenda Cossman, The Precarious Unity of Feminist Theory and Practice: The Praxis of Abortion, 44 U. Toronto FAC. L. REV. 85, 107 (1986).

141. See Hutchinson \& Petter, Private Rights, supra note 73.

142. Harris, 448 U.S. at 316. 
of private responsibility also makes it possible to blame the poor, who are overwhelmingly women, for their inability to be self-sufficient. ${ }^{143}$

A progressive vision has a different understanding of social life and its possibilities for justice. It would accommodate the fact that women are different than men in their reproductive characteristics, understand the socio-political relations that frame and valorize those facts, and ensure that any understanding of what it is to be a full moral being incorporates the vital material dimension of women's lives. ${ }^{144}$ Recognition that subordination is reinforced by ignoring the relevance of social conditions that give rise to that subordination in the first place is essential. Consequently, a non-liberal theory of public responsibility begins with the inseparable connection between social conditions and the individual exercise and experience of personal autonomy. So instructed, it looks beyond the negative legalisms of rights-talk to the affirmative politics of a needs-oriented social agenda. As a practice of communal solidarity, it concerns itself as much with social welfare as it does individual privacy.

Of course, the fact is that les misérables are not accorded the privilege of choosing the institutional site or rhetorical conditions of their struggle for social transformation. Nevertheless, this is neither as significant nor as debilitating as might first be thought. The first step to enlightenment is the recognition that there is no available "outside" from which to engage in transformative action: all struggle is already situated within the mechanisms that are to be resisted and reworked. Struggle must commence from where we are and with the historical problems and possibilities of the present. The only available strategy is to develop legal tactics that politicize and disrupt the courts in the process of using them for litigation. ${ }^{145}$ The challenge is to engage in law and, at the same time, to delegitimize it by eschewing abstract notions of justice and rights in favor of concrete challenges.

The worst implication to be drawn by lawyers from the abortion decisions would be to believe that, by making the correct arguments and

143. Rhonda Copelon, Unpacking Patriarchy: Reproduction, Sexuality, Originalism, and Constitutional Change, a Less Than Perfect Union, in A LESS ThAN PERFECT UNION 303, 323 (Jules Lobel ed., 1988).

144. See Rosalind P. Petchesky, Abortion and Woman's Choice: The State, SexualITY, AND Reproductive Freedom (1984); Zillah R. Eisenstein, Feminism and Sexual EQUALITY (1984).

145. For a power-oriented rather than right-centered approach to law practice, see Peter Gabel \& Paul Harris, Building Power and Breaking Images: Critical Legal Theory and the Practice of Law, 11 N.Y.U. Rev. L. \& Soc. ChANGe 369 (1983); see also Carol Smart, Feminism and Law: Some Problems of Analysis and Strategy, 14 INT'L J. Soc. L. 109 (1986). 
by following the same doctrinal logic, it will be possible to consolidate gains made or achieve further successes. To do this would be to take too seriously the transformative power of abstract reasoning and to endow the legal process with a spurious legitimacy. It remains true that, in a political culture which grants an increasingly significant place to litigation and in which rights-talk possesses a special resonance, claims phrased in the rhetoric of rights might be less easily rejected and might act as a catalyst for the mobilization of popular struggle. As such, it might be feasible and successful on occasion to point out the frequency with which contemporary society fails to live up to its own expectations. Nevertheless, in general, it will only be by maintaining a thoroughgoing skepticism of such talismanic tendencies and by recognizing the strategic significance of such litigation in particular socio-economic circumstances that the viability of any resorts by progressive lawyers to the courts can be sustained. ${ }^{146}$

The greatest danger of a rights litigation strategy is that it might succeed occasionally, but often enough to warrant continued faith in its efficacy as the chosen venue for progressive struggle. The attempt to make a silk purse of social justice out of the pig's ear of constitutional jurisprudence becomes too easily a waste of radical zeal. With any apparent success, it is vital not to forget that adjudicative success (or failure) only marks the end of one phase of struggle and the beginning of another. It is not a triumph (or a defeat) unless the legal currency can be converted into a negotiable instrument for real social change. Most importantly, when a legal success is achieved, it must be remembered what it is that is being celebrated-it is not the institution of the Supreme Court or the process of constitutional adjudication. To fete the institution or the process is to pave the way for long-term disaster. For when the institution or the process produces a decision that is hostile to progressive interests or overrules an earlier supportive decision, that decision will be endowed with the imprimatur of political legitimacy. Ironically, this will have been achieved because of, and not in spite of, the activists' efforts.

What ought to be celebrated is the substance of the decision itself and its potential concrete effects. Another bench on another day might

146. The record of the civil rights movements offers evidence of the limited successes (and substantial dangers) of obliging the political and legal establishment to honor its own half-hearted commitment to the universal dimension of rights talk. See Richard Delgado, The Ethereal Scholar: Does Critical Legal Studies Have What Minorities Want?, 22 HARv. C.R.-C.L. L. REV. 301 (1987); Kimberle W. Crenshaw, Race, Reform and Retrenchment: Transformation and Legitimation in Antidiscrimination Law, 101 HaRv. L. REv. 1331 (1988). 
use the cover of the Bill of Rights to smite, not protect, the same interests. ${ }^{147}$ It is crucial to acknowledge that success was not due to lawyers or constitutional charters, but to the political force of committed women coming together and working together. It was a triumph of popular will that made it possible for the Supreme Court to decide as it did in Roe. Whether Roe is eviscerated or invigorated will also be decided by the ideological dynamics of public action and most definitely not by the imminent rationality of constitutional law. That a majority of judges had the foresight and the courage in 1973 to heed the democratic call for gender justice is a cause for jubilation. But Roe ought not be a rallyingcall for constitutional enchantment: one swallow does not a progressive summer make.

As well as perpetuating the idea that justice comes from a judicial act of noblesse oblige rather than a product forged at the anvil of social struggle, a dependence on litigation struggles over rights will dissipate much valuable energy that could be better used elsewhere. Direct citizen involvement is always to be preferred to constitutional litigation. At the heart of any progressive campaign for social justice, there must be a firm commitment to the development of popular coalitions so that the disenfranchised can become part of their own empowerment. If a true democracy is to be the goal, it must be effected by means that are themselves thoroughly democratic in nature. The shift from less of an individualcentered and rights-based approach to more of a group-based and poweroriented program will facilitate ambition. In this way, it might become possible to "recognize and accommodate the political importance of process over legal goals and build links with communities whose perspectives" are not usually or easily represented in the practices of constitutional litigation. ${ }^{148}$

At best, the courts and, therefore, constitutional litigation, can never be more than a surgical aid to an ailing political system. The more appropriate progressive response is to treat the cause of the malaise rather than its symptoms by working to democratize better the political process. Continued resort to the courts to resolve political issues reinforces the undemocratic view that the political and representative forums are inappropriate and ineffective; it will become an unfortunate self-fulfilling prophesy. The vast energies and resources of lawyers are better deployed in legislative reform than in ingenious litigation: Lawyers are the only real long-term beneficiaries of the present obsession with courts.

147. See Frances Olsen, Unravelling Compromise, 103 Harv. L. Rev. 105 (1989).

148. Sherene RaZaCK, Canadian Feminism and the Law 57 (1991). 
It is perverse to liken judicial review to a dialogue or debate between citizens and the State about the reasonableness of government action. ${ }^{149}$ If there is any debate, it is between different branches of government: Citizens' complaints only provide an occasion for a discussion in which those citizens can listen hopefully and speak episodically in the highpriced words of an arcane legal vocabulary. Democracy demands that citizens are more than eavesdroppers at the doors of power.

\section{CONCLUSION}

In one of the great characterizations of literature, Hugo creates Inspector Javert, the archetypical embodiment of law. He is the incarnation of unbending legalism and the symbol of righteous rectitude. With a "vulture gaze"150 and leading "a life of unswerving duty," man with a profound instinct for correctitude, regularity, and probity, and with a consuming hatred for the vagabond order to which he himself belonged."152 In short, "law and order, morality, government, the whole of society, were personified in [him]." 153 Like an indignant bloodhound, he tracks Jean Valjean throughout his life. Their episodic encounters represent the clash between the popular pressures for social change and the established forces of authoritarian order. But, in the melodramatic denouement to their titanic engagements, Javert is caught in the throes of indecision. His life having been saved by Jean Valjean, he is confronted by an irresolvable choice between the unfamiliar promptings of his conscience to let Jean Valjean go free and the life-long dictates of his social duty to apprehend a convicted felon. Racked by the anguish of uncertainty and like "an owl required to see with eagle's eyes,"154 he was forced to admit that "there may be error in dogma, that society is not perfect ... that judges are men and even the law may do wrong."155 Tormented and contrite, he takes his own life.

Perhaps, like Javert, judges must retire from the social scene if justice is to prevail. Yet, even when faced with their own complicity in les misérables' wretchedness, it is unlikely that courts and lawyers will effect such a noble or final retreat. Chastised by critics for its rigidity, the law

149. See Owen M. Fiss, Foreword: The Forms of Justice, 93 HARv. L. Rev. 1, 14-15 (1978).

150. Hugo, supra note 1 , at 169.

151. Id. at 166.

152. Id. at 165 .

153. Id. at 188.

154. Id. at 1106 .

155. Id. at 1107 . 
has learned to bend more and to cope better with contradiction. Formalism has proved to have unexpectedly durable and adaptable qualities. Indeed, the rhetorical life of contemporary law may be the intense experience of its own contradictory logic. ${ }^{156}$ Paradoxically, the best way to push courts and litigators out of the social action is for political activists and progressive lawyers to pull themselves away. Without constitutional litigation to invigorate it, the judicial process might wither away as the leading institutional organ for social policy-making. As a matter of contingent wisdom, it is a definite case of less being more.

Like everything else, the problem with poverty is that its abasements become bearable to its wretched victims and that it is accepted as inevitable by those who perpetuate its condition. Although legal activists, like Hershkoff and Cohen, might castigate the judges in Young and mainstream society for perpetuating a phantom normalcy in which the problems of les misérables are diminished and dismissed, they manage to perpetuate that condition. By allowing beggars the constitutional privilege to "speak to the broader society about the pain of being poor,"157 they give formal recognition to the poor as natural residents of contemporary American society. This moves people to anguish, but not to action. It is not formal status or rights that they crave or that we should wish to bestow. Rights only work for those who are already privileged. To others, they are a travesty of justice. It is change, not its promise, that is needed. Neither patronizing nor romanticizing les misérables, the ambition must be to embrace everyone with the arms of a society that truly cares for the plight of all. To do otherwise is to run the risk of turning on its head Anatole France's ironic lament for "the majestic equality of the laws, which forbid rich and poor alike to sleep under the bridges, to beg in the streets, and steal bread."158

It is not enough to invite beggars to the bourgeois banquet so that they can, at least once, experience the good life. This not only demeans the guests and makes the hosts feel undeservedly beneficent, but it works as an almost celebratory occasion for "the way things are." To paraphrase Marx, the beggar is not freed from the tyranny of private property, but receives the dubious freedom to beg for it. ${ }^{159}$ Not only does a right to beg not change the underlying structure of private property and

156. See Allan C. Hutchinson, Democracy and Determinacy: An Essay in Legal Interpretation, 43 U. Miami L. Rev. 541 (1989).

157. See Hershkoff \& Cohen, supra note 18 , at 912.

158. ANatole France, The Red Lily 91 (Winifred Stephens trans., 1970).

159. See Karl Marx \& Frederick Engels, On the Jewish Question (1843), in 3 Collected WORKS 146, 164 (1975). 
its unequal distribution, but it places that very structure of capital accumulation outside the activist agenda of transformative possibilities. Any non-liberal vision of social justice must understand and be prepared to alter fundamentally the structural conditions that entrench the misery and humiliation that is the enduring lot of the pathetic panhandler. A progressive campaign for moral self-realization and political enlightenment must address these deep sources of institutional injustice that frame and valorize the lives of rich and poor alike.

It is a profound error to talk about poverty without also talking about wealth. There should be no talk about food banks without talk about investment banking; no talk about empty plates without talk about food mountains; no talk about the working poor without talk about the idle rich; and no talk about the homeless without talk about the property speculator. If poverty has a moral or immoral dimension, it will not be found in the habits and characteristics of the poor and homeless, but in the routines and rationalizations of the rich and propertied. Moreover, those who are presently privileged and committed to eradicating poverty must not be content to speak for and on behalf of les misérables. They must have a place of their own from which to speak and nurture a voice of their own in which to speak. Beggars are only saved when they no longer exist. Their salvation demands nothing less than that their suffering become ours too. And still we ask-"who is to blame?"160

160. Hugo, supra note 1 , at 640 . 